\title{
CROPS AND SOILS RESEARCH PAPER Spacing between rows: effects on water-use efficiency of double-cropped wheat and soybean
}

\author{
X. B. Zhou ${ }^{1}$, Y. H. Chen ${ }^{*}$ AND Z. Ouyang ${ }^{2}$ \\ ${ }^{1}$ National Engineering Lab. for Efficient Utilization of Soil and Fertilizer Resources, State Key Lab. of Crop Biology, \\ Agronomy College of Shandong Agricultural University, Taian 271018, People's Republic of China \\ 2 Key Laboratory of Ecosystem Network Observation and Modeling, Institute of Geographic Sciences and Natural \\ Resources Research, Chinese Academy of Sciences, Beijing, People's Republic of China
}

(Received 9 April 2013; revised 10 September 2013; accepted 27 October 2013; first published online 16 December 2013)

\section{SUMMARY}

Productivity and water resource usage efficiency are crucial issues in sustainable agriculture. The aims of the present research were to compare and evaluate the soil moisture content (SMC), evapotranspiration (ETa), yield, water-use efficiency (WUE), and net return of winter wheat (Triticum aestivum L.) and soybean [Glycine max (L.) Merr.] under different plant population distribution patterns and to identify the possible ways to improve water utilization. Using the same plant population for a given crop, the experiments consisted of four spacings between rows (row spacings) for winter wheat (cvar Shannong 919) under both rainfed and irrigated conditions and five row spacings for summer soybean (cvar Ludou 4) under rainfed conditions. For winter wheat, the stem number with row spacing of $49 \mathrm{~cm}$ was the lowest in all treatments. The SMC was enhanced by irrigation, particularly at the $10-40 \mathrm{~cm}$ depth. The yield and WUE were negatively correlated with row spacing and were greater with narrower row spacing than with wider rows. For soybean, SMC in uniform distribution (spacing between plants) treatments was greater at lower depths than at shallower depths for each row spacing treatment. A high yield, WUE and net return of winter wheat and soybean can be achieved with narrower row spacing. Combining winter wheat row spacing of $14 \mathrm{~cm}$ with soybean row spacing of $18 \mathrm{~cm}$ and soybean row spacing of $27 \mathrm{~cm}$ is a highly suitable planting system for the plains of Northern China.

\section{INTRODUCTION}

Winter wheat and soybean are cultivated extensively in China. In 2010, c. 3.56 and 0.16 million hectares of wheat and soybean were grown in Shandong Province, with a mean grain yield of 5780 and $2459 \mathrm{~kg} / \mathrm{ha}$, respectively. The Huanghuaihai Plain, an alluvial flood plain located in a sub-humid continental monsoon zone in Northern China, is one of the most important winter wheat and summer soybean production areas with an annual accumulated temperature $\left(\geqslant 0{ }^{\circ} \mathrm{C}\right)$ of $4800^{\circ} \mathrm{C}$, an annual average rainfall of $600 \mathrm{~mm}$, a cumulative annual solar radiation of over $5200 \mathrm{MJ} / \mathrm{m}^{2}$ and a frost-free period of $>200$ days. The average precipitation in Taian, China,

* To whom all correspondence should be addressed. Email: yhchen@sdau.edu.cn and ouyz@igsnrr.ac.cn is $697 \mathrm{~mm} /$ year (1971-2008), and the greatest monthly precipitation $(182 \mathrm{~mm})$ and temperature $\left(25.7^{\circ} \mathrm{C}\right)$ occur during the hot summer months of July and August.

During the growing season, the water requirements of winter wheat (c. 400-500 mm) exceed the average rainfall received, therefore requiring supplemental irrigation; in contrast, summer soybean is generally grown without irrigation. Spacing between rows (row spacing) influences the plant population's structure and yield (Eberbach \& Pala 2005; Zhou \& Chen 2011), whereby inter-plant competition can occur when the supply of a single essential factor for growth falls below the aggregate demands of all the plants (Avola et al. 2008; Abadouz et al. 2010). If sown sufficiently close to one another, a plant can influence its neighbour and modify its soil or atmospheric environment, thereby 
decreasing the growth rate (De Bruin \& Pedersen 2008; Zhou et al. 2011a). The main competition factors for plants include light, water and nutrients (Brant et al. 2009); therefore, the row spacing of plants influences their yield (Herbert \& Baggerman 1983; Farnham 2001; Asokan et al. 2005; Kazemeini et al. 2009; Cox \& Cherney 2011; Stevovic et al. 2012). In addition, a lower yield is associated with increasing soil water deficits (Mishra et al. 1999).

Improving water-use efficiency (WUE) to optimize the benefits of irrigation is of paramount importance to farmers (Mishra et al. 1995; Ritchie \& Basso 2008), as irrigation water is becoming an increasingly scarce resource in many areas of Northern China (Jiang 2009). Consequently, appropriate irrigation scheduling and planting patterns are necessary to optimize the yield and maximize net return; furthermore, management practices to maintain yield while minimizing external input requirements are necessary to ensure economic and environmental sustainability (Hill et al. 2006). Wheat-legume rotation systems with additional nitrogen input during the wheat growth phase not only maintain sustainable production systems but are also more efficient at utilizing limited rainfall than continuous wheat systems (Pala et al. 2007). The appropriate application of water (i.e. rainfed and irrigated conditions) and row spacing has a large influence on the yield and optimal wheat and soybean plant populations (Zhou et al. 2011a).

Previous investigations of WUE have primarily dealt with crops grown under limited water conditions and have not considered the relationship between crop row spacing and WUE (Lehrsch et al. 1994; Bowers et al. 2000), with the crop yield obtained merely reflecting the amount of stored soil water, rainfall, irrigation water and plant population distribution patterns. Indeed, agricultural practices should be developed for different ecological regions, considering that plant water consumption during reproductive periods depends mostly on plant growth in addition to soil and climatic conditions. Therefore, an optimal row spacing and plant density have been implemented under various water regimes (Bhullar et al. 2002; Lambert \& Lowenberg-DeBoer 2003; Uçan et al. 2007; Zhang et al. 2008; Fang et al. 2010; Tarkalson et al. 2011). The objective of the present study was to determine the effect of row spacing on the WUE of winter wheat and summer soybean under rainfed and irrigated conditions. An evaluation of the combined responses of winter wheat and soybean to water and row spacing could help identify the optimal allocation

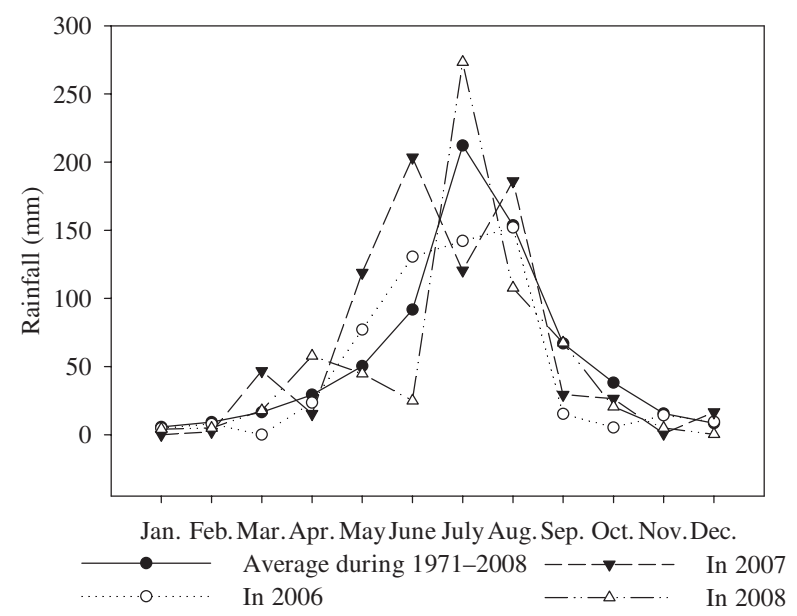

Fig. 1. Average monthly rainfall during 1971-2008 and monthly rainfall from 2006 to 2008 .

of available resources among crops in this cropping system to maximize net returns. The present study aims to: (i) evaluate the effect of row spacing and its interaction with the water supply for wheat and soybean cropped in a warm, temperate continental monsoon climate and (ii) identify the optimum row spacing for a soybean-wheat rotation system in annual double cropping in Northern China.

\section{MATERIALS AND METHODS}

Site description

This research was conducted at the Agronomy Experimental Station of Shandong Agricultural University, Taian $\left(36^{\circ} 09^{\prime} \mathrm{N}, 117^{\circ} 09^{\prime} \mathrm{E}, 134 \mathrm{~m}\right.$ asl) in Northern China. The site is representative of the Huanghuaihai Plain, the main winter wheat growing region in North China. At this station, the long-term (1971-2008) average rainfall and temperature are $697 \mathrm{~mm}$ and $12 \cdot 8^{\circ} \mathrm{C}$, respectively, with c. $200 \mathrm{~mm}$ of total rainfall during the winter wheat growing season (October-June). The 4 ha study area is mapped as silt loam (pH 6.9) and has slopes of $0^{\circ}-3^{\circ}$ (USDA 1979). At the experimental site, the average nutrients at a depth of $0-20 \mathrm{~cm}$ were tested from 2006 to 2008 before the winter wheat planting, with a soil organic matter content of $16 \cdot 3 \mathrm{~g} / \mathrm{kg}$ and total, $\mathrm{P}$ and $\mathrm{K}$ concentrations of $1.3 \mathrm{~g} / \mathrm{kg}, 35 \mathrm{mg} / \mathrm{kg}$ and $95 \mathrm{mg} / \mathrm{kg}$, respectively.

Weather data were collected from the Taian Agrometeorological Experimental Station located $500 \mathrm{~m}$ from the experimental site. The data for the long-term monthly rainfall from January to December (1971-2008) are shown in Fig. 1. During the winter 
wheat growing season, the total rainfall values in 2006/ 07 and 2007/08 were 213 and $170 \mathrm{~mm}$, respectively; during the summer soybean growing season, the total rainfall values in 2006, 2007 and 2008 were 439, 539 and $448 \mathrm{~mm}$, respectively.

\section{Experimental design}

The experiments were conducted during the respective crop growing seasons from June 2006 to September 2008. As part of a continuous winter wheat-summer soybean rotation experiment, the previous crop plants (soybean or winter wheat) were hand-harvested and their residues were removed. The experimental design was a randomized complete block for both winter wheat and soybean with three replications. The field plots were superimposed on the same position each year. Each plot was $3 \times 3 \mathrm{~m}$ in size. It was a split-plot arrangement of treatments for winter wheat. Water conditions were allocated as main plots and spacing between rows were split-plots. Winter wheat (cvar Shannong 919) was hand-planted at $408 \mathrm{seeds} / \mathrm{m}^{2}$ on 6 October 2006 and 10 October 2007, and the seedlings were thinned by hand 5 days after emergence to obtain uniform final plant population densities $\left(204 \mathrm{plant} / \mathrm{m}^{2}\right)$. The experiment consisted of four plant population distribution patterns under rainfed and irrigated conditions. The row spacing $\times$ spacing between plants schemes used were $7 \times 7 \mathrm{~cm}$ (row spacing 7 , a uniform grid pattern), $14 \times 3.5 \mathrm{~cm}$ (row spacing 14), $24.5 \times 2 \mathrm{~cm}$ (row spacing 24.5) and $49 \times 1 \mathrm{~cm}$ (row spacing 49). Summer soybean seeds (cvar Ludou 4) were hand-sown and were superimposed on the same plot location after the irrigated wheat was harvested, at a seeding rate of $62 \mathrm{seeds} / \mathrm{m}^{2}$ on 12 June 2006, 13 June 2007 and 18 June 2008. All the plots were thinned to $31 \mathrm{plant} / \mathrm{m}^{2}$ 5 days after soybean emergence to obtain uniform final plant population densities. The experiment consisted of five plant population distribution patterns under rainfed conditions. The row spacing $\times$ spacing between plants schemes used were $18 \times 18 \mathrm{~cm}$ (row spacing 18 , a uniform grid pattern), $27 \times 12 \mathrm{~cm}$ (row spacing 27), $36 \times 9 \mathrm{~cm}$ (row spacing 36), $45 \times 7.2 \mathrm{~cm}$ (row spacing 45 ) and $54 \times 6 \mathrm{~cm}$ (row spacing 54 ). The seeding of winter wheat and soybean was at $2-3 \mathrm{~cm}$ and $3-4 \mathrm{~cm}$ soil depths, respectively. The plots were managed using a no-till production system. Dicot weeds in the winter wheat plots were controlled chemically by applying the herbicide $0.84 \mathrm{~kg} / \mathrm{ha}$ 2-methyl-4-clorophenoxyacetic acid (MCPA); other winter wheat and weeds of soybean weeds were removed by hand.

To prevent the lateral flow of soil water, concrete slabs were inserted at $200 \mathrm{~cm}$ deep at a width of $15 \mathrm{~cm}$ on all sides of each plot, and plastic film $(0 \cdot 1 \mathrm{~mm}$ thick) was placed along the concrete wall. For the irrigated winter wheat plants, $60 \mathrm{~mm}$ of water was applied at Zadoks growth stages (GSs) 35 (stem elongation stage), GS49 (booting stage) and GS71 (milk development stage) on 31 March, 25 April, 14 May 2007, on 2 April, 2 May and 18 May 2008, respectively (Zadoks et al. 1974). Water was conveyed from the outlet of a pump to the plots using plastic pipes, and a flow meter was used to measure the amount of water applied. The winter wheat plants were harvested on 5 June 2007 and 13 June 2008 and summer soybean on 25 September 2006, 25 September 2007 and 24 September 2008. The number of stems in the winter wheat was determined using a $1 \mathrm{~m}^{2}$ quadrat per plot at the GS29, GS35, GS47 and GS57. The crop yield was measured with two $1 \mathrm{~m}^{2}$ quadrats per plot.

\section{Soil moisture measurements}

Aluminium access tubes ( $45 \mathrm{~mm}$ internal diameter) for use with a neutron moisture meter were installed $1.3 \mathrm{~m}$ deep between the rows near the centre of each plot prior to sowing (one tube per plot). The soil moisture content (SMC) was monitored every 7-10 days throughout the crop growing seasons at $10 \mathrm{~cm}$ intervals from 20 to $120 \mathrm{~cm}$ below the soil surface using a local field-calibrated CNC503B Neutron Moisture Probe (Super Energy Nuclear Technology, Ltd., Beijing, China). The moisture content of the top $20 \mathrm{~cm}$ of the soil profile was determined using a CS620 portable time-domain reflectometry system (Campbell Scientific Australia Pty. Ltd., Townsville, Australia).

\section{Computation and statistical analyses}

The evapotranspiration (ETa) in each treatment was computed using climate data obtained from the Taian Agrometeorological Experimental Station with the following equations:

$E T a=\Delta W+I+R-S I-Q$

where $E T a$ is the total amount of seasonal evapotranspiration $(\mathrm{mm}), \Delta W$ is the change in the stored soil water (mm, Kang et al. 2004), l is the amount of irrigation water $(\mathrm{mm}), R$ is the amount of rainfall $(\mathrm{mm})$, 


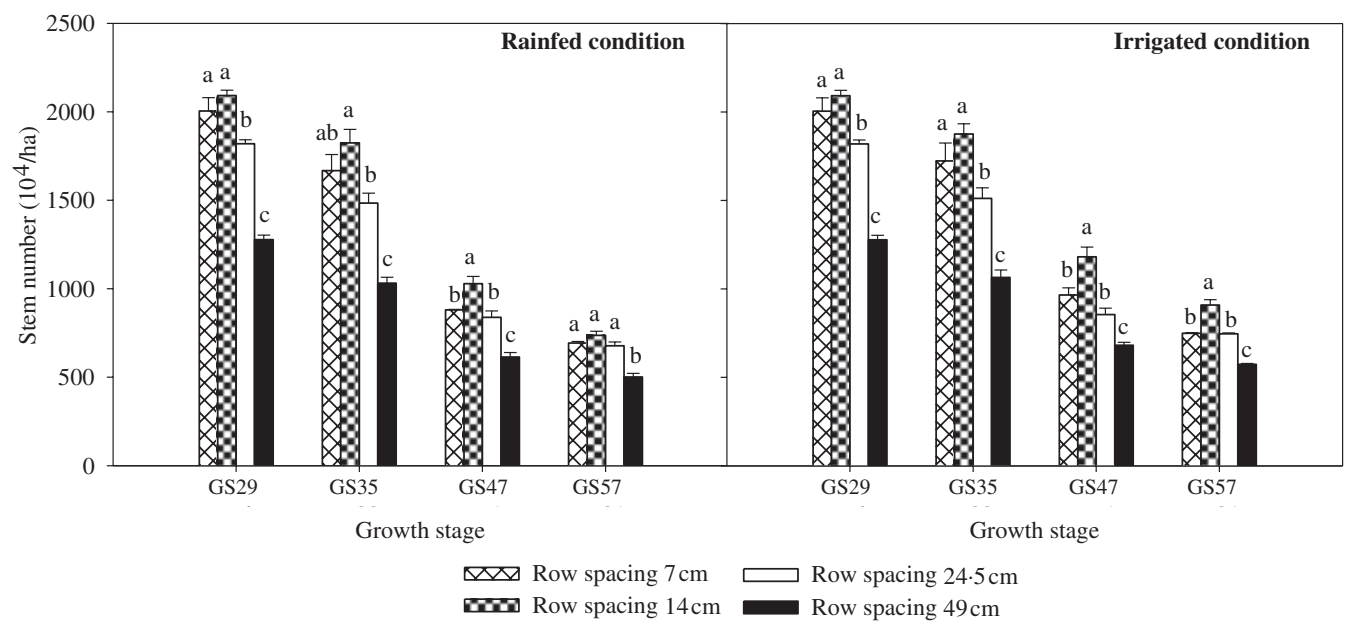

Fig. 2. Stem number at different growth stages of winter wheat under rainfed and irrigated conditions. The values are averages of the 2006/07 and the 2007/08. The error bars are the s.E. Within a growth stage, the treatment means with the same lowercase letters are not significantly different according to $P \leqslant 0 \cdot 05$.

$S I$ is the depth of deep percolation $(\mathrm{mm})$, and $Q$ is the amount of surface run-off $(\mathrm{mm}) . \mathrm{S} /$ was estimated using the approach proposed by Gong \& Li (1995). Based on the observations for the winter wheat growing seasons, the surface run-off was negligible.

$S I=W_{i}-F K$

where $W_{i}$ is the water stored in the $i$ soil layer $(\mathrm{mm})$ and $F K$ is the field capacity $(\mathrm{mm})$.

$W U E=Y / E T a$

where $Y$ is the grain yield $(\mathrm{kg} / \mathrm{ha})$ of the crops.

$N R=T I-T C$

where $N R$ is the net return, $T I$ is the total income (the value of the harvested winter wheat and soybean) and $T C$ is the total costs (including the costs of all inputs, such as winter wheat and soybean seed, fertilizer, pesticide and labour).

$$
\begin{aligned}
A E W U E= & \left(Y_{W} \times E V W+Y_{S} \times E V s\right) /(E t a w \\
& + \text { Etas })
\end{aligned}
$$

where $A E W U E$ is the annual energy-water use efficiency; $Y_{W}$ and $Y s, E V W$ and $E V s$, and Etaw and Etas are the yield, energy value (EV) and Eta of winter wheat and soybean, respectively, and $E V W$ and $E V s$ are 15730 and $20670 \mathrm{~kJ} / \mathrm{kg}$, respectively.

In the combined analyses, each site-year was considered as a fixed effect, where they were considered to be unique based solely on the same site. Water conditions and spacing between rows also were considered fixed effects. Replications were considered random effects. All the data were analysed using the FIXED model for the analysis of variance (ANOVA) (Everitt \& Hothorn 2006). The experimental data were analysed using ANOVA to determine whether significant differences existed among the means of the different treatments.

\section{RESULTS}

\section{Winter wheat stem number}

The changes in the wheat stem number due to row spacing and the time of year were similar between the rainfed and irrigated treatments (Fig. 2), with irrigation and row spacing demonstrating a great impact on individual plants during growth. The stem number at the GS29 and GS35 were greater than those in the GS47 and GS57. After irrigation, the SMC increased by $11-56 \%$ during GS35 and GS57 (data not shown); under these water conditions, crop growth was improved and the stem populations were larger than under the rainfed conditions from GS35 to GS57. The stem number at the different row spacings can be ranked as row spacing $14>$ row spacing $7>$ row spacing 24.5>row spacing 49; row spacing 7 and row spacing 14 resulted in higher stem numbers than the other row spacing treatments, whereas there were significantly fewer stems at row spacing $49(P<0 \cdot 05)$. The results show that the number of winter wheat stems at wide row spacings was the lowest in all the treatments. From the GS29 to GS57, the stem numbers at row spacing 7 , row spacing 14 , row spacing $24 \cdot 5$, and row spacing 49 rapidly decreased to $65,65,63$ and $61 \%$ under the rainfed conditions, respectively, 


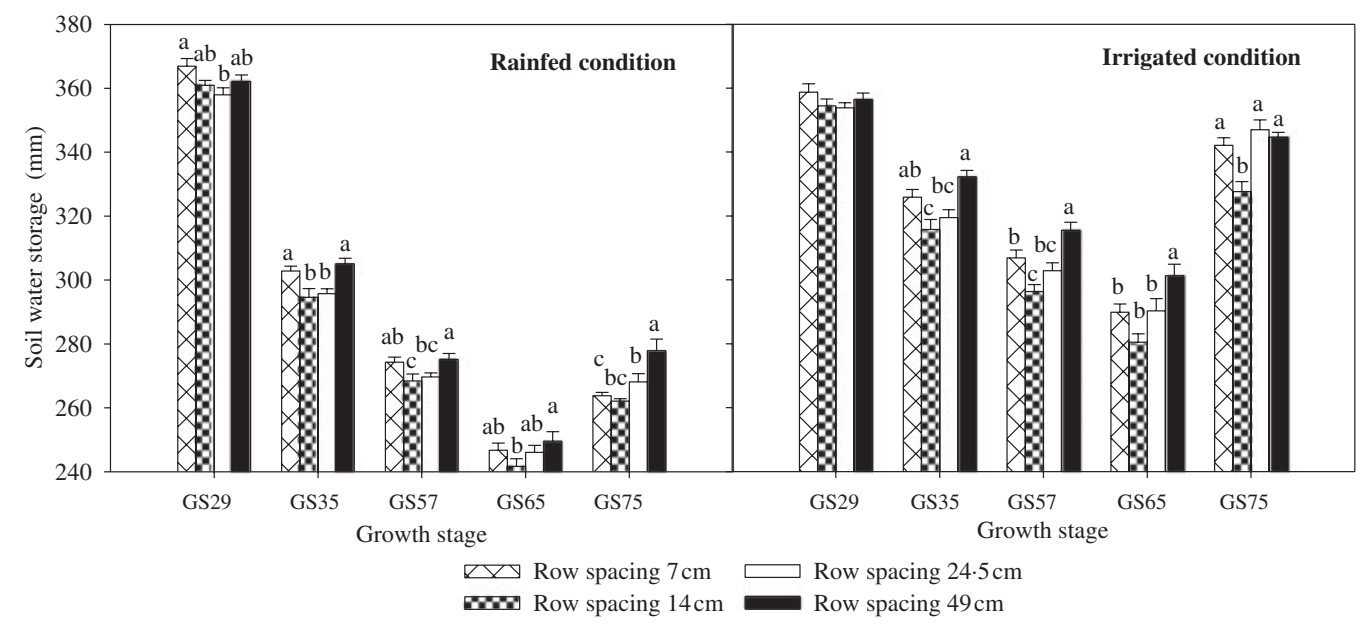

Fig. 3. Changes in soil water storage in a winter wheat field. The values are the average at a $0-120 \mathrm{~cm}$ soil depth in the 2006/07 and 2007/08 growing seasons. The error bars are the S.E. Within a growth stage, the treatment means with the same lowercase letters are not significantly different according to $P \leqslant 0 \cdot 05$.

with no significant differences observed. Similarly, stem numbers at the same row spacing were reduced to $63,57,59$ and $55 \%$ for the irrigated conditions, with row spacing 7 being significantly higher than the other treatments and row spacing 49 being significantly lower than row spacing 7 and row spacing 14 $(P<0 \cdot 05)$.

Changes in soil water storage and soil moisture content in winter wheat

The changes in the winter wheat soil water storage (SWS) averages in 2006/07 and 2007/08 are given in Fig. 3. At the same row spacing treatment, the SWS of the irrigated condition was significantly higher than that of the rainfed condition $(P<0 \cdot 05)$. The average SWSs of the row spacing 7 , row spacing 14 , row spacing 24.5 and row spacing 49 treatments were 291, 286, 288 and $294 \mathrm{~mm}$, respectively, for the rainfed conditions, and they were 325, 315, 323 and $330 \mathrm{~mm}$, respectively, for the irrigated conditions. The row spacing 49 treatment showed the highest SWS (Fig. 3). The SWS at the GS35 was greater than that at other GSs, and the minimum was observed at the GS65. The SWS of the different treatments showed a descending trend with advancing GS.

Irrigation had a significant effect on SMC: after irrigation, SMC was evidently enhanced, particularly at the $10-40 \mathrm{~cm}$ soil depth $(P<0 \cdot 05)$. The SMC increased by $18 \%$ for the entire winter wheat growing season. The curve shape for SMC resembles the letter Z for the different treatments for 2006/07 and 2007/08, and the inflection point of the curve can be observed at the 40 and $70 \mathrm{~cm}$ soil depths. The average SMCs for both the rainfed and irrigated conditions at the 0-120 cm soil depths, from seeding to maturity, can be ranked as row spacing $14<$ row spacing $24 \cdot 5<$ row spacing $7 \approx$ row spacing 49 . No significant differences were recorded between the treatments. The SMC of row spacing 14 was the lowest and that of row spacing 24.5 was mid-range. No evident difference was found in the SMC values between row spacing 7 and row spacing 49 (Fig. 4).

Changes in soil water storage and soil moisture content in soybean

During the 2006-08 growing seasons, the ranking based on the SWS average values for the different treatments was row spacing $18>$ row spacing $45>$ row spacing $27>$ row spacing $36>$ row spacing 54 , with the respective values being 283, 279, 275, 275 and $273 \mathrm{~mm}$, respectively. Spacing between rows had no significant effect on SWS during growth except for vegetative stages VE-V6 (Ritchie et al. 1994). Prior to reproductive stages R3-R4 (Ritchie et al. 1994), the SWS value was the highest in the row spacing 18 treatment with the results of all other treatment being similar. The row spacing 18 treatment showed a 4\% higher SWS than the averages for the other treatments. From R5-R6 to R7-R8, the SWS of the row spacing 45 treatment produced the highest SWS, and no evident differences were found among the other treatments. The maximum SWS of the different treatments 


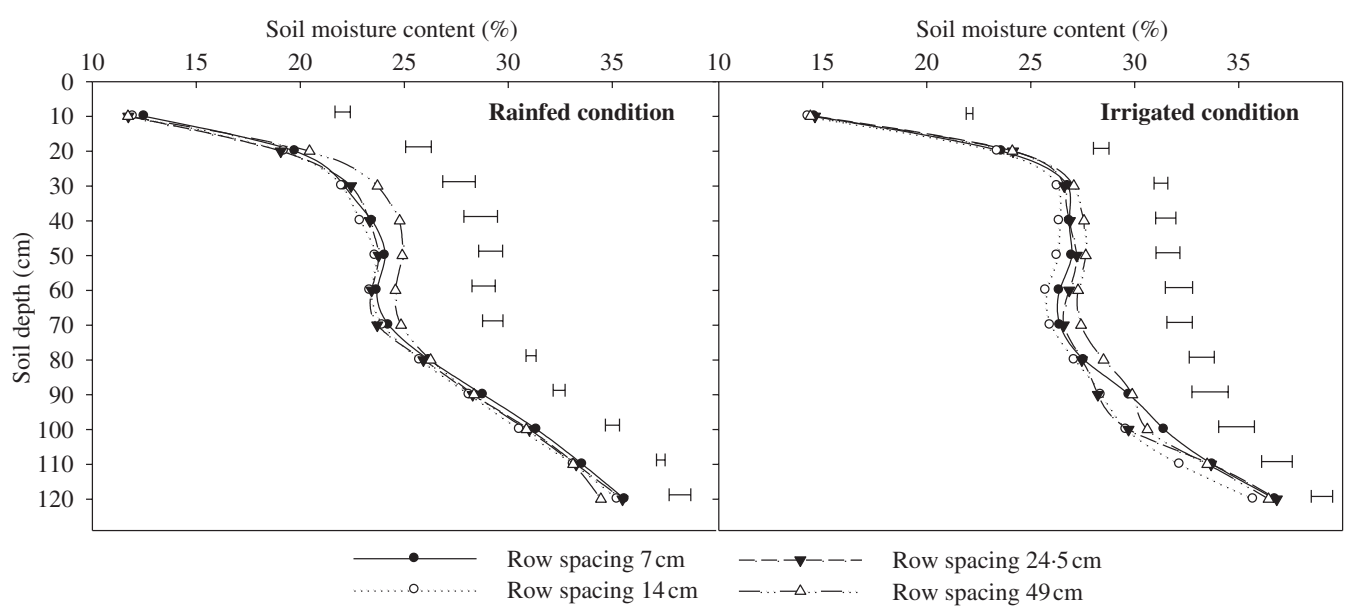

Fig. 4. Changes in the soil moisture content in a winter wheat field. The values are the average of the 2006/07 and 2007/ 08 growing seasons. Error bars =s.D.

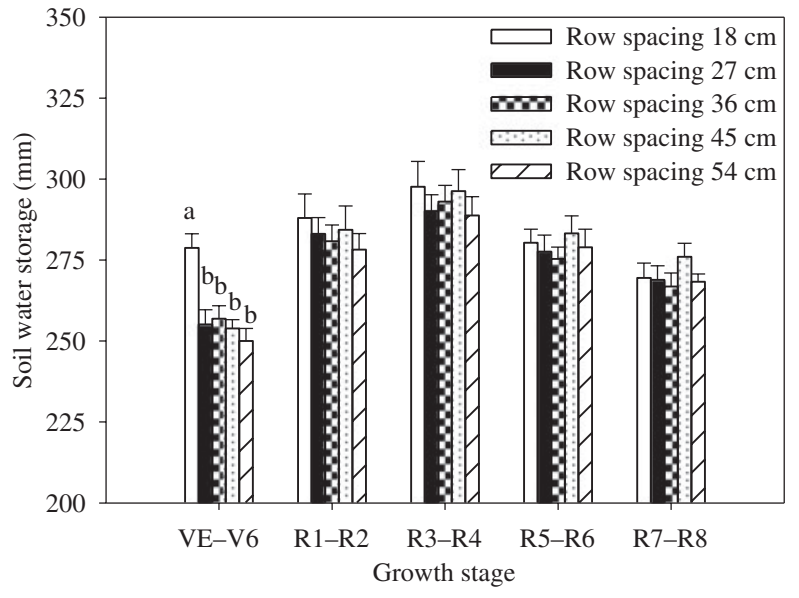

Fig. 5. Changes in the soil water storage in a soybean field. The values are the average at a $0-120 \mathrm{~cm}$ soil depth in the 2006-08 growing seasons. Error bars=s.D. Within a growth stage, the treatment means with the same lowercase letters are not significantly different according to $P \leqslant 0.05$.

appeared at R3-R4, which may be related to the increase in rainfall pre- and post-R3-R4 (Fig. 5).

The shapes of the curves for SMC in the different treatments during the 2006-08 growing seasons are similar to that of wheat, and the inflection points of the curves appear at the 40 and $70 \mathrm{~cm}$ soil depths (Fig. 6). The SMC in the lower layers was greater than in the upper layers for each row spacing treatment. The SMC was significantly enhanced in the $20-40 \mathrm{~cm}$ and 70 $120 \mathrm{~cm}$ soil depths $(P<0 \cdot 05)$. For the entire summer soybean growing season, the ranking based on the SMC average at $0-120 \mathrm{~cm}$ was row spacing $18>$ row spacing $54>$ row spacing $45>$ row spacing $27 \approx$ row spacing 36. Therefore, the plant population

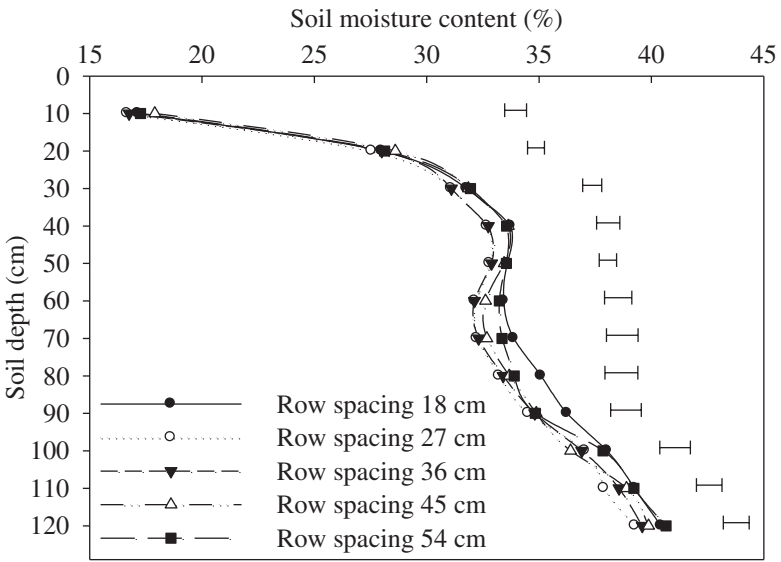

Fig. 6. Changes in soil moisture content in a soybean field. The values are the average of the 2006-08 growing seasons. Error bars $=$ s.D.

distribution patterns influenced the SMC differences between the treatments, but no significant differences were recorded.

Evapotranspiration, yield and water-use efficiency of winter wheat

In 2006/07 and 2007/08, the yield and ETa of the winter wheat irrigated plots were higher than those of the rainfed plots, whereas the WUE values were lower. The linear equation of yield $v$. row spacing was as follows: $y($ yield, $\mathrm{kg} / \mathrm{ha})=-24.535 \times($ row spacing, $\mathrm{cm})$ $+7666.7, \quad R^{2}=0.3219 \quad(P<0.05$, rainfed $)$ and $y=$ $-23 \cdot 241 \times+8696 \cdot 2, R^{2}=0 \cdot 5368(P<0 \cdot 001$, irrigated $)$; the linear equation of ETa $v$. row spacing was as follows: $y(E t a, m m)=-0.6378 \times($ row spacing, $\mathrm{cm})$ 
Table 1. Effects of row spacing (RS) on the yield, evapotranspiration (ETa) and water-use efficiency (WUE) of winter wheat

\begin{tabular}{|c|c|c|c|c|c|c|c|}
\hline \multirow[b]{2}{*}{ WC } & \multirow[b]{2}{*}{$\mathrm{RS}(\mathrm{cm})$} & \multicolumn{2}{|c|}{ Yield (kg/ha) } & \multicolumn{2}{|c|}{$\mathrm{ETa}(\mathrm{mm})$} & \multicolumn{2}{|c|}{ WUE (kg/ha/mm) } \\
\hline & & $2006 / 07$ & 2007/08 & 2006/07 & $2007 / 08$ & $2006 / 07$ & $2007 / 08$ \\
\hline \multirow[t]{6}{*}{ Rainfed } & 7 & 6960 & 7710 & 330 & 335 & $21 \cdot 1$ & $23 \cdot 0$ \\
\hline & 14 & 7080 & 7760 & 335 & 333 & $21 \cdot 2$ & $23 \cdot 3$ \\
\hline & $24 \cdot 5$ & 6820 & 7590 & 312 & 317 & $21 \cdot 9$ & $24 \cdot 0$ \\
\hline & 49 & 5500 & 7280 & 305 & 311 & $18 \cdot 0$ & $23 \cdot 4$ \\
\hline & S.E.D. & 112 & 66 & $2 \cdot 1$ & $1 \cdot 2$ & $0 \cdot 36$ & $0 \cdot 20$ \\
\hline & (D.F.) & (8) & (8) & (8) & (8) & (8) & (8) \\
\hline \multirow[t]{5}{*}{ Irrigated } & 7 & 8240 & 8550 & 466 & 427 & $17 \cdot 7$ & $20 \cdot 0$ \\
\hline & 14 & 8360 & 8670 & 490 & 438 & $17 \cdot 1$ & $19 \cdot 8$ \\
\hline & $24 \cdot 5$ & 7950 & 8360 & 450 & 413 & $17 \cdot 7$ & $20 \cdot 3$ \\
\hline & 49 & 6950 & 8090 & 482 & 406 & $14 \cdot 4$ & $20 \cdot 0$ \\
\hline & $\begin{array}{l}\text { S.E.D. } \\
\text { (D.F.) }\end{array}$ & $\begin{array}{l}72 \\
(8)\end{array}$ & $\begin{array}{l}35 \\
(8)\end{array}$ & $\begin{array}{c}1 \cdot 8 \\
(8)\end{array}$ & $\begin{array}{c}1 \cdot 1 \\
(8)\end{array}$ & $\begin{array}{l}0 \cdot 15 \\
(8)\end{array}$ & $\begin{array}{l}0 \cdot 08 \\
(8)\end{array}$ \\
\hline Source & D.F. & \multicolumn{6}{|c|}{$P>F$} \\
\hline WC & 1 & $<0.001$ & $<0.001$ & $<0.001$ & $<0.001$ & $<0.001$ & $<0.001$ \\
\hline RS & 3 & $<0.001$ & $<0 \cdot 001$ & $<0.001$ & $<0 \cdot 001$ & $<0.001$ & $<0.001$ \\
\hline $\mathrm{WC} \times \mathrm{RS}$ & 3 & NS & NS & $<0 \cdot 001$ & $<0 \cdot 001$ & NS & $<0.05$ \\
\hline
\end{tabular}

WC, water condition.

$+337 \cdot 21, R^{2}=0 \cdot 7796(P<0 \cdot 001$, rainfed $)$. The trend analysis was not significant between ETa and row spacing (irrigated), WUE and row spacing (rainfed and irrigated). The yield and ETa for row spacing 14 were the highest among the treatments, being 16 and $8 \%$ (rainfed) and 13 and 5\% (irrigated) higher than those of the row spacing 49 treatment, respectively. The yield resulting from row spacing 49 was significantly lower than those of the other treatments $(P<0 \cdot 05)$. These results show a consistent change in the individual plants during GS57. The average ETas for the two growing seasons of row spacing 7 , row spacing 14 , row spacing $24 \cdot 5$, and row spacing 49 were $332,334,314$ and $308 \mathrm{~mm}$ (rainfed) and 446, 464,432 and $444 \mathrm{~mm}$ (irrigated), respectively (Table 1). The WUE of row spacing 24.5 was higher than that in the other treatments. The ranking of treatments by WUE was row spacing $24 \cdot 5>$ row spacing $7 \approx$ row spacing $14>$ row spacing 49 (rainfed) and row spacing $24 \cdot 5 \approx$ row spacing $7>$ row spacing $14>$ row spacing 49 (irrigated), respectively. The total amount of rainfall for 2006/07 and 2007/08 was 213 and $170 \mathrm{~mm}$, respectively, but the yields were reversed. From October to December 2007, the total amount of rainfall for July was $42 \mathrm{~mm}$, which is $13 \mathrm{~mm}$ more than that of 2006, and this high amount of rainfall improved the tillering of the winter wheat. There was $119 \mathrm{~mm}$ of rainfall in May 2006, and this factor may have been responsible for the lack of relationship between yield and rainfall. Furthermore, the amount of rainfall and irrigation water did not affect the trend in yield changes of the different planting styles for winter wheat. In contrast, water conditions and row spacing had a significant effect on all traits, with the water conditions $\times$ row spacing interaction being significant only for Eta $(P<0 \cdot 001)$.

Evapotranspiration, yield and water-use efficiency of soybean

The row spacing showed observable effects on the soybean yield, Eta and WUE during the course of the present study (Table 2). Significant negative correlations were observed between the yield and row spacing over the 3 years and with the following linear equation: $y=-11.682 \times+2461 \cdot 1, R^{2}=0.9299$ $(P<0 \cdot 001)$. The yields of the row spacing 18 and row spacing 27 treatments were significantly higher than those of the row spacing 45 and row spacing 54 treatments $(P<0 \cdot 05)$, whereas no significant differences were observed among the row spacing 36 , row spacing 45 and row spacing 54 treatments in 2007 and 
Table 2. Effects of row spacing (RS) on the yield, evapotranspiration (ETa) and water-use efficiency (WUE) of soybean

\begin{tabular}{|c|c|c|c|c|c|c|c|c|c|}
\hline \multirow[b]{2}{*}{$\mathrm{RS}(\mathrm{cm})$} & \multicolumn{3}{|c|}{ Yield (kg/ha) } & \multicolumn{3}{|c|}{$\mathrm{ETa}(\mathrm{mm})$} & \multicolumn{3}{|c|}{ WUE (kg/ha/mm) } \\
\hline & 2006 & 2007 & 2008 & 2006 & 2007 & 2008 & 2006 & 2007 & 2008 \\
\hline 18 & 1600 & 2620 & 2450 & 313 & 444 & 307 & $5 \cdot 1$ & $5 \cdot 9$ & $8 \cdot 0$ \\
\hline 27 & 1580 & 2640 & 2360 & 310 & 450 & 314 & $5 \cdot 1$ & $5 \cdot 9$ & $7 \cdot 5$ \\
\hline 36 & 1550 & 2340 & 2210 & 301 & 452 & 323 & $5 \cdot 1$ & $5 \cdot 2$ & $6 \cdot 8$ \\
\hline 45 & 1360 & 2270 & 2180 & 320 & 450 & 328 & $4 \cdot 3$ & $5 \cdot 0$ & $6 \cdot 6$ \\
\hline 54 & 1170 & 2200 & 2110 & 306 & 451 & 341 & $3 \cdot 8$ & 4.9 & $6 \cdot 2$ \\
\hline $\begin{array}{l}\text { S.E.D. } \\
\text { (D.F.) }\end{array}$ & $\begin{array}{r}30 \\
(10)\end{array}$ & $\begin{array}{r}86 \\
(10)\end{array}$ & $\begin{array}{r}48 \\
(10)\end{array}$ & $\begin{array}{r}7 \cdot 7 \\
(10)\end{array}$ & $\begin{array}{r}1 \cdot 6 \\
(10)\end{array}$ & $\begin{array}{r}5 \cdot 5 \\
(10)\end{array}$ & $\begin{array}{l}0 \cdot 09 \\
(10)\end{array}$ & $\begin{array}{l}0 \cdot 34 \\
(10)\end{array}$ & $\begin{array}{l}0 \cdot 06 \\
(10)\end{array}$ \\
\hline
\end{tabular}

Table 3. The net return and annual energy-water use efficiency (AEWUE) of the combination of irrigated winter wheat with rainfed soybean

\begin{tabular}{|c|c|c|c|c|c|c|c|c|c|}
\hline \multirow[b]{3}{*}{ SRS (cm) } & & \multicolumn{8}{|c|}{ WRS (cm) } \\
\hline & & 7 & 14 & $24 \cdot 5$ & 49 & 7 & 14 & $24 \cdot 5$ & 49 \\
\hline & & \multicolumn{4}{|c|}{ Net return (\$/year/ha) } & \multicolumn{4}{|c|}{ AEWUE $\left(\mathrm{kJ} / \mathrm{m}^{2} / \mathrm{mm}\right)$} \\
\hline \multicolumn{2}{|l|}{18} & 3900 & 3940 & 3820 & 3610 & $22 \cdot 3$ & $22 \cdot 0$ & $22 \cdot 2$ & $20 \cdot 6$ \\
\hline \multicolumn{2}{|l|}{27} & 3910 & 3950 & 3830 & 3620 & $22 \cdot 2$ & $22 \cdot 0$ & $22 \cdot 2$ & $20 \cdot 6$ \\
\hline \multicolumn{2}{|l|}{36} & 3770 & 3810 & 3690 & 3470 & $21 \cdot 7$ & $21 \cdot 4$ & $21 \cdot 6$ & $20 \cdot 0$ \\
\hline \multicolumn{2}{|l|}{45} & 3680 & 3720 & 3600 & 3380 & $21 \cdot 2$ & $21 \cdot 0$ & $21 \cdot 1$ & $19 \cdot 6$ \\
\hline \multicolumn{2}{|l|}{54} & 3600 & 3640 & 3520 & 3300 & $20 \cdot 9$ & $20 \cdot 7$ & $20 \cdot 8$ & $19 \cdot 3$ \\
\hline \multicolumn{2}{|l|}{ S.E.D. } & 63 & 55 & 54 & 62 & $0 \cdot 23$ & $0 \cdot 18$ & $0 \cdot 19$ & $0 \cdot 23$ \\
\hline \multicolumn{2}{|l|}{ (D.F.) } & (10) & $(10)$ & (10) & (10) & (10) & (10) & $(10)$ & $(10)$ \\
\hline Source & D.F. & \\
\hline SRS & 3 & \multicolumn{4}{|c|}{$<0.001$} & \multicolumn{4}{|c|}{$<0 \cdot 001$} \\
\hline WRS & 4 & \multicolumn{4}{|c|}{$<0.001$} & \multicolumn{4}{|c|}{$<0.001$} \\
\hline $\mathrm{SRS} \times \mathrm{WRS}$ & 12 & \multicolumn{4}{|c|}{ NS } & \multicolumn{4}{|c|}{ NS } \\
\hline
\end{tabular}

SRS, soybean row spacing.

WRS, wheat row spacing.

2008. The yields of the row spacing 18 and row spacing 27 treatments were 37 and 35\% (in 2006), 19 and $22 \%$ (in 2007), and 16 and $12 \%$ (in 2008), respectively, higher than those of the row spacing 54 treatment. Negligible (and in most cases, not significant) differences in ETa were observed between the treatments in 2006 and 2007, with larger differences observed in 2008. Significantly negative correlations were observed between WUE and row spacing with the following linear equation: $y=-0 \cdot 0404 x+7 \cdot 1532$, $R^{2}=0.9334(P<0.001)$. The WUE of the row spacing 18 and row spacing 27 treatments was significantly higher than that in the row spacing 45 and row spacing 54 treatments, respectively $(P<0 \cdot 05)$. The yield for the three years can be ranked as $2007>2008>2006$, with rainfall amounts of 539, 448 and $440 \mathrm{~mm}$, respectively. In 2008, the total amount of rainfall for July was $273 \mathrm{~mm}$, which was crucial to the growth and yield of the soybean plants. Thus, the WUE value for 2008 was greater than that of 2006 and 2007. The rainfall did not lead to a trend in yield changes for the different planting treatments.

Annual energy-water use efficiency and net return

Plant population distribution patterns evidently influenced AEWUE and the annual net return (Table 3), and similar characteristics were observed for the changes in the rainfed plots. Under the same row spacing of winter wheat, the ranking by net return and AEWUE 
per year for the soybean-wheat system was row spacing $18 \approx$ row spacing $27>$ row spacing $36>$ row spacing $45>$ row spacing 54 . A significantly negative correlation was observed between net return and row spacing and between AEWUE and row spacing, with $r$ values of -0.9816 and -0.9908 , respectively $(P<0.05)$. The averages for row spacing 18 and row spacing 27 were 7 and $6 \%$ higher than those of row spacing 45 and row spacing 54, respectively. Under the same soybean row spacing, the ranking by annual net return for winter wheat was row spacing $14>$ row spacing $7>$ row spacing $24.5>$ row spacing 49 ; the ranking by AEWUE was row spacing $14 \approx$ row spacing $24 \cdot 5>$ row spacing $7>$ row spacing 49 . The $r$ values between net return and row spacing, and between AEWUE and row spacing, were $-0.9540 \quad(P<0.05)$ and -0.8479 , respectively, and the average AEWUE and annual net return for row spacing 14 was 10 and $7 \%$ higher, respectively, than those of row spacing 49 . The wheat and soybean row spacings were significant for every trait, but the effect of their interaction was not significant for net return and AEWUE.

\section{DISCUSSION}

For winter wheat, the stem number in narrow row spacings was greater than in wide ones. This result can be attributed to increased interplant competition and greater plant mortality in the latter, where the spacing between plants in wider row spacings is much closer than in narrower ones. These results are similar to those obtained by Henderson et al. (2000): intense competition was observed in the late GS, with stem number decreasing, and irrigation improved the crop growth conditions and increased the number of stems.

During the winter wheat growing season, row spacing did not exhibit any observable effects on SMC; indeed, the differences in SMC throughout the growth period were caused by irrigation and rainfall. The SMC of the row spacing 14 treatment was low, which may be attributable to ETa. The soil profile water status greatly affects the density and depth of root penetration and often restricts the full utilization of the available soil water (Angadi \& Entz 2002; Zuo et al. 2006). An upward hydraulic gradient in the root zone and an upward capillary flux may have occurred in the deeper soil layers (Bandyopadhyay et al. 2005). Therefore, although there was a slight decline in SMC at the $60 \mathrm{~cm}$ soil depth, no SMC scarcity was found for the roots at the $90-120 \mathrm{~cm}$ soil depth. The variation in SWS was similar to that in SMC. Soil water storage showed a decreasing trend with advancing GS, which may have been related to the rapid crop growth and increased water consumption in the middle and late periods of crop growth.

During the soybean growing season, soil evaporation and crop transpiration affected SMC and were the major factors affecting SMC at the different soil layers. As shown by the changes in the plant population distribution patterns, the effects of soil evaporation and crop transpiration on SMC varied between the row spacing treatments used. The lack of adequate moisture necessary for a plant to grow normally and complete its life cycle (Zhu 2002) is often a key factor that limits plant growth, productivity and survival (Namirembe et al. 2009; Kamiloğlu 2011). The differences in the SMC profiles across the treatments within the years studied reveal that changes in plant arrangement produce different water extraction benefits under rainfed conditions. The SWS of row spacing 18 was comparatively higher during R3-R4, probably because of the reduction in soil water evaporation due to the uniform pattern created. Additionally, wider row spacing decreased the water requirement of individual plants at reproductive stages R5-R8, whereas inter-plant competition inhibited plant growth during vegetative stages VE-V6.

Irrigation increased the winter wheat ETa. Previous work demonstrated that the GS01-GS35 is a critical period that influences the plant population size (Zhou et al. 2007). The row spacing 14 treatment produced the largest plant population size, whereas row spacing 49 yielded the lowest; in effect, the row spacing $14 \mathrm{ETa}$ was significantly higher compared with the other treatments. In the present study, irrigation increased the yield and ETa but decreased WUE. The present results are similar to previous findings showing that grain yield is related to ETa (Schneider \& Howell 1997; Huang et al. 2004). A row spacing of $12 \mathrm{~cm}$ resulted in a higher spatial plant distribution and increased crop ground cover, leaf area index, dry matter and light interception (Drews et al. 2009). Consequently, a relatively uniform distribution (row spacing 14) promoted crop yield even at a high ETa.

Soil water lost to the atmosphere via soil evaporation from beneath the crop canopy is highly variable and varies with row spacing and the growing season (Yunusa et al. 1993; Eberbach \& Pala 2005). The water-use efficiency of the row spacing 18 and row spacing 27 treatments was significantly higher than 
that of the row spacing 45 and row spacing 54 treatments, respectively, and these findings are attributed to the narrow row treatments used. A greater yield with equivalent levels of water extraction results in a greater WUE. Thus, the row spacing 45 and row spacing 54 treatments showed evident inter-plant competition, creating a field microclimate. The leaf water status varies greatly among different row spacings (Zhou et al. 2011b, 2012). Indeed, negative correlations were observed between WUE and row spacing, whereas significantly positive correlations were found between WUE and yield, similar to the results of Ethredge et al. (1989) and Holshouser \& Whittaker (2002).

Annual energy-water use efficiency helps in the comparison of the differences in the planting systems used under annual double cropping, such as a wheatsoybean or wheat-maize rotation. Evapotranspiration was greater in the row position than in the inter-row position and the high ETa resulted in water loss, impaired water supply and decreased yield (Ohashi et al. 2000; Timlin et al. 2001). In a wide row spacing, the competition among plants within a row may increase and the use of water resources may not be maximized; a narrow row spacing often increases crop competitiveness and improves the plant population structure and field habitat. The narrow row spacing resulted in a lower ETa and higher yield than the wide row spacing. Thus, the net return and AEWUE of the wheat and soybean combination with uniform plant population distribution patterns were better than those of the other patterns.

\section{CONCLUSIONS}

The 2-year study on wheat demonstrated that the yield of irrigated winter wheat was significantly higher than that of rainfed winter wheat. Thus, the production of winter wheat in the Huanghuaihai Plain cannot be achieved without irrigation because of the scarce precipitation in the area during the growing season. Moreover, row spacing affected the yield and ETa of the winter wheat plants and a high wheat yield may also be achieved in Northern China by reducing row spacing. The row spacing 7 yield was higher than the row spacing 24.5 and row spacing 49 yields. However, this planting pattern is difficult to practice in agricultural production in which seeds are sown by tractor operations. Given these findings and based on the yield and WUE, row spacing 14 is optimal for this region.
This 3-year study on soybean demonstrated that the enhanced productivity and WUE of rainfed soybean can be achieved in Northern China by reducing the row spacing and widening the space between plants. Similar SMC values across treatments within the 3 study years indicate that changes in the plant arrangement of summer soybean yield no benefits for extracting more water under rainfed agriculture. The conclusion of the present study regarding soybean is that row spacing of $\leqslant 27 \mathrm{~cm}$ is optimal for this region.

Significant negative correlations were observed among the net return, AEWUE and row spacing values under the same row spacing of winter wheat and soybean. The plant population distribution affected the WUE, yield and net return of winter wheat and soybean, and the relatively uniform population distribution pattern was better than the other patterns. Based on the results of our study, combining soybean-row spacing 18 or soybean-row spacing 27 with winter wheat-row spacing 14 is optimal for the wheatsoybean cropping system in North China.

Sincere acknowledgments are due to Shujuan Sun, Guomin Yang, Lin Qi for field assistance. This research was supported by the National High Technology Research and Development Programme of China (grant no. 2013AA102903), the Special Fund for Agro-scientific Research in the Public Interest (grant no. 200903040) and the National Key Technology Support Programme of China (grant no. 2012BAD14B07).

\section{REFERENCES}

Abadouz, G., Hasanzadeh Gorttapeh, A., Rahnema, A. A. \& Behradfar, A. (2010). Effect of row spacing and seeding rate on yield component and seed yield of Alfalfa (Medicago sativa L.). Notulae Scientia Biologicae 2, 74-80.

AnGADI, S. V. \& Entz, M. H. (2002). Root system and water use patterns of different height sunflower cultivars. Agronomy Journal 94, 136-145.

Asokan, S., Murthi, A. N. \& Mahadevaswamy, M. (2005). Effect of nitrogen levels and row spacing on yield, CCS and nitrogen uptake in different sugarcane varieties. Sugar Technology 7, 44-47.

Avola, G., Tuttobene, R., Gresta, F. \& Abbate, V. (2008). Weed control strategies for grain legumes. Agronomy for Sustainable Development 28, 389-395.

Bandyopadhyay, P. K., Mallick, S. \& Rana, S. K. (2005). Water balance and crop coefficients of summer-grown peanut 
(Arachis hypogaea L.) in a humid tropical region of India. Irrigation Science 23, 161-169.

Bhullar, M. S., Saini, L. K., Kapur, M. L. \& Singh, S. (2002). Effect of method and density of planting on growth and yield of late planted sugarcane. Sugar Technology 4, 181184.

Bowers, G. R., RabB, J. L., Ashlock, L. O. \& SANtin, J. B. (2000). Row spacing in the early soybean production system. Agronomy Journal 92, 524-531.

Brant, V., Neckář, K., Pivec, J., Duchoslav, M., Holec, J., Fuksa, P. \& Venclová, V. (2009). Competition of some summer catch crops and volunteer cereals in the areas with limited precipitation. Plant, Soil and Environment $\mathbf{5 5}$, 17-24.

Cox, W.J. \& Cherney, J.H. (2011). Growth and yield responses of soybean to row spacing and seeding rate. Agronomy Journal 103, 123-128.

De Bruin, J. L. \& Pedersen, P. (2008). Effect of row spacing and seeding rate on soybean yield. Agronomy Journal 100, 704-710.

Drews, S., Neuhoff, D. \& KÖPKE, U. (2009). Weed suppression ability of three winter wheat varieties at different row spacing under organic farming conditions. Weed Research 49, 526-533.

Eberbach, P. \& Pala, M. (2005). Crop row spacing and its influence on the partitioning of evapotranspiration by winter-grown wheat in Northern Syria. Plant and Soil 268, 195-208.

Ethredge, W. J., Ashley, D. A. \& Woodruff, J. M. (1989). Row spacing and plant population effects on yield components of soybean. Agronomy Journal 81, 947951.

EVEritT, B. S. \& Hothorn, T. (2006). A Handbook of Statistical Analyses Using R. Boca Raton, FL, USA: Chapman \& Hall/ CRC.

Fang, X., Turner, N. C., Yan, G., Lı, F. \& Siddique, K. H. M. (2010). Flower numbers, pod production, pollen viability, and pistil function are reduced and flower and pod abortion increased in chickpea (Cicer arietinum L) under terminal drought. Journal of Experimental Botany 61, 335345.

FARNHAM, D.E. (2001). Row spacing, plant density, and hybrid effects on corn grain yield and moisture. Agronomy Journal 93, 1049-1053.

GonG, Y. S. \& LI, B. G. (1995). Using field water balance model to estimate the percolation of soil water. Advances in Water Science 6, 16-21. (In Chinese with English abstract)

Henderson, T. L., Johnson, B. L. \& Schneiter, A. A. (2000). Row spacing, plant population, and cultivar effects on grain amaranth in the northern Great Plains. Agronomy Journal 92, 329-336.

Herbert, S. J. \& Baggerman, F. D. (1983). Cowpea response to row width, density and irrigation. Agronomy Journal 75, 982-986.

Hill, J., Nelson, E., Tilman, D., Polasky, S. \& Tiffany, D. (2006). Environmental, economic, and energetic costs and benefits of biodiesel and ethanol biofuels. Proceedings of the National Academy of Sciences of the United States of America 103, 11206-11210.
Holshouser, D. L. \& Whittaker, J. P. (2002). Plant population and row-spacing effects on early soybean production systems in the Mid-Atlantic USA. Agronomy Journal 94, 603-611.

Huang, M., Gallichand, J. \& Zhong, L. (2004). Water-yield relationships and optimal water management for winter wheat in the Loess Plateau of China. Irrigation Science 23, 47-54.

JIANG, Y. (2009). China's water scarcity. Journal of Environmental Management 90, 3185-3196.

KAMILOĞLU, Ö. (2011). Influence of some cultural practices on yield, fruit quality and individual anthocyanins of table grape cv. 'Horoz Karasi'. Journal of Animal and Plant Sciences 21, 240-245.

KANG, Y.H., WANG, F.X., LIU, H.J. \& YUAN, B.Z. (2004). Potato evapotranspiration and yield under different drip irrigation regimes. Irrigation Science 23, 133-143.

Kazemeini, S. A., Edalat, M. \& Shekoofa, A. (2009). Interaction effects of deficit irrigation and row spacing on sunflower (Helianthus annuus L.) growth, seed yield and oil yield. African Journal of Agricultural Research 4, 11651170.

Lambert, D. M. \& Lowenberg-DeBoer, J. (2003). Economic analysis of row spacing for corn and soybean. Agronomy Journal 95, 564-573.

Lehrsch, G. A., Whisler, F. D. \& Buehring, N. W. (1994). Cropping system influences on extractable water for mono-and double-cropped soybean. Agricultural Water Management 26, 13-25.

Mishra, H. S., Rathore, T. R. \& Tomar, V. S. (1995). Water use efficiency of irrigated wheat in the Tarai region of India. Irrigation Science 16, 75-80.

Mishra, H.S., Rathore, T.R. \& Tomar, V.S. (1999). Root growth, water potential and yield of irrigated wheat. Irrigation Science 18, 117-123.

Namirembe, S., Brook, R.M. \& Ong, C. K. (2009). Manipulating phenology and water relations in Senna spectabilis in a water limited environment in Kenya. Agroforestry Systems 75, 197-210.

Ohashi, Y., SANeOKa, H. \& Fujta, K. (2000). Effect of water stress on growth, photosynthesis, and photoassimilate translocation in soybean and tropical pasture legume siratro. Soil Science and Plant Nutrition 46, 417425.

Pala, M., Ryan, J., Zhang, H., Singh, M. \& Harris, H. C. (2007). Water-use efficiency of wheat-based rotation systems in a Mediterranean environment. Agricultural Water Management 93, 136-144.

Ritchie, J. T. \& BAsso, B. (2008). Water use efficiency is not constant when crop water supply is adequate or fixed: the role of agronomic management. European Journal of Agronomy 28, 273-281.

Ritchie, S. W., Hanway, J. J., Thompson, H. E. \& Benson, G. O. (1994). How a soybean plant develops. In Special Report 53, Rev (Ed. I. Ames). USA: lowa State University Cooperative Extension Service.

SChneider, A. D. \& Howell, T. A. (1997). Methods, amounts, and timing of sprinkler irrigation for winter wheat. Transactions of the ASAE 40, 137-142. 
Stevovic, V., Stanisavljevic, R., Duukic, D. \& Duurovic, D. (2012). Effect of row spacing on seed and forage yield in sainfoin (Onobrychis viciifolia Scop.) cultivars. Turkish Journal of Agriculture and Forestry 36, 35-44.

Tarkalson, D. D., King, B. A., Bjorneberg, D. L. \& Taberna, J. P. Jr. (2011). Evaluation of in-row plant spacing and planting configuration for three irrigated potato cultivars. American Journal of Potato Research 88, 207-217.

Timlin, D., Pachepsky, Y. \& Reddy, V.R. (2001). Soil water dynamics in row and interrow positions in soybean (Glycine max L.). Plant and Soil 237, 25-35.

Uçan, K., Killı, F., GençoǦlan, C. \& Merdun, H. (2007). Effect of irrigation frequency and amount on water use efficiency and yield of sesame (Sesamum indicum L.) under field conditions. Field Crops Research 101, 249-258.

USDA. (1979). Soil Survey for Jim Wells County, Texas, Washington, DC, USA: United States Department of Agriculture/Soil Conservation Service.

Yunusa, I. A. M., Sedgley, R. H., Belford, R. K. \& Tennant, D. (1993). Dynamics of water use in a dry mediterranean environment. I. Soil evaporation little affected by presence of plant canopy. Agricultural Water Management 24, 205224.

Zadoks, J. C., ChanG, T. T. \& KonZaK, C. F. (1974). A decimal code for the growth stages of cereals. Weed Research 14, 415-421.

Zhang, X., Chen, S., Sun, H., Pel, D. \& Wang, Y. (2008). Dry matter, harvest index, grain yield and water use efficiency as affected by water supply in winter wheat. Irrigation Science 27, 1-10.

ZHOU, X. B. \& CHeN, Y. H. (2011). Yield response of winter wheat to row spacing under irrigated and rainfed conditions. Bulgarian Journal of Agricultural Science 17, 158166.

Zhou, X. B., Lı, Q. Q., Yu, S. Z., Wu, W. \& Chen, Y. H. (2007). Row spacing and irrigation effects on water consumption of winter wheat in Taian, China. Canadian Journal of Plant Science 87, 471-477.

Zhou, X. B., Chen, Y. H. \& OUyanG, Z. (2011a). Row spacing effect on leaf area development, light interception, crop growth and grain yield of summer soybean crops in Northern China. African Journal of Agricultural Research 6, 1430-1437.

Zhou, X. B., Qı, L., YANG, G. M. \& Chen, Y. H. (2011b). Row spacing effect on soil and leaf water status of summer soybean. Journal of Animal and Plant Sciences 21, 680685.

Zhou, X. B., Sun, S. J., YanG, G. M., Chen, Y. H. \& Liu, P. (2012). Farmland microclimate and yield of Triticum aestivum under different row spacing. Tarım Bilimleri Dergisi 18, 1-8.

ZHU, J. K. (2002). Salt and drought stress signal transduction in plants. Annual Review of Plant Biology 53, 247-273.

ZuO, Q., SHI, J., LI, Y. \& ZHANG, R. (2006). Root length density and water uptake distributions of winter wheat under subirrigation. Plant and Soil 285, 45-55. 